nal é a em que predominam as grandes instituições financeiras nascidas depois de Bretton Woods. Após a Segunda Grande Guerra aparecerem três tipos de instituições financeiras, a saber, o Banco Mundial e todas as cópias de instituições de desenvolvimento nos países do Terceiro Mundo; os bancos de desenvolvimento; e os bancos de financiamento das exportações como: Eximbank, Ermez, CCFAZ, Export and Credit Garantee Sistems, na Inglaterra, etc. Registram-se financiamentos de programas meio assistenciais ou não, tipo Plano Marshall, AID, programas de cooperação dentro da Commonwelth, dentro da União Francesa, etc. Nessa segunda etapa, evidentemente, o projeto atinge o auge. Condição básica para a obtenção de financiamento nas instituições financeiras era a apresentação do projeto com estudo de viabilidade, com cash-flow, de preferência numa moeda que aparecia sacrossanta, o dólar.

A terceira etapa do financiamento internacional coincide com o mundo pós-OPEP, o do mercado do eurodólar, do financiamento à base do projeto, e está afetado hoje pela invasão de eurodólares, que chegaram ao mercado e, como o professor Sadek El Kosheri demonstrou, colocaram o Banco Mundial como instituição de financiamento relativamente secundária, isto é, o fluxo de financiamentos obtidos hoje no mercado de eurodólares é infinitamente superior aos recursos que são canalizados através das instituições clássicas de financiamento internacional na base de projetos.

De modo que, nessas três fases de financiamento internacional, ligeiramente recapituladas, poderíamos talvez falar - para tomar um título de um livro de Salvador Magalhaga El alvia delclínio - do projeto com o mecanismo de obtenção de financiamentos internacionais. Essa visão histórica, creio que tem certa importância porque há grande fluidez nas relações econômicas internacionais e nós estamos assistindo, a cada dia, a imaginação dos comerciantes - a que se referia Alberto Venâncio - que inventaram as sociedades anônimas, os títulos de crédito, etc., a inventar novos mecanismos de mobilização de recursos financeiros internacionais que ficam disponíveis ora aqui, ora ali, ora em países exportadores de petróleo, ora em países exportadores de alimentos, etc.

\title{
Financiamento do balanço de pagamentos
}

Sílvio Hitoshi Yanagawa, consultor jurídico do Banco Central do Brasil

Estamos realmente atravessando fase muito difícil para as nossas exportações e há dificuldade ainda maior para conseguirmos financiamentos no mercado internacional.

Temos observado nos últimos tempos que, mais do que o agravamento da balança comercial, o balanço de pagamentos tem sido onerado pelos juros e serviços da dívida. Acredito que poderíamos evitar uma situação mais grave para os países do Terceiro Mundo, em geral, na medida em que pudéssemos obter financiamentos mais fáceis, ou melhor, menos caros.

Conforme já foi frisado aqui várias vezes, o mercado de eurodólares é que tem prevalecido como fonte de financiamento do balanço de pagamentos de vários países. Ora, esse é um mercado que gira em torno de taxas de juros de prime-rate, ou de li-

\section{Sílvio Hitoshi Yanagawa}

bor. E são taxas muito altas que, para os projetos de longa maturação, não podem ser aplicadas, uma vez que o retorno do capital é demorado e custoso.

Ora, temos projetos de cuja viabilidade jamais poderíamos duvidar, como o Projeto Carajás, o Projeto do Cerrado, e outros. Então, acredito que, uma vez que as fontes institucionais estão sendo esgotadas e os recursos são curtos, essa tentativa de fazer intercâmbio entre países do Terceiro Mundo, contexto em que se registra a colaboração venezuelana e a dos Fundos Árabes, é, sobremodo, interessante. E creio, como advogado, ainda, que foi muito interessante essa exposição do Fundo Árabe para evitar a incidência de juros, recorrer a outros instrumentos que não envolvessem a cobrança de juros. Eé nesse sentido que os advogados devem trabalhar, usando imaginação, desenvolvendo a construção jurídica, trocando experiências. 